\title{
Linked Lives across Borders: Economic Remittances to Ageing Parents in Romania
}

\author{
lonuț Földes
}

\begin{abstract}
Economic support is widespread among multigenerational Romanian family units separated by national borders and plays an important role for nonmigrating family members. From a political economy perspective, remittances are characteristic of such long-term kin networks, which in turn are shaped by sociostructural contexts. This study aims to analyse transfers of remittances in cash and in kind from emigrant Romanian adult children to elderly parents back home. Both forms of upward support are investigated under the lens of family practices across distance. Data from a survey (Intergenerational solidarity in the context of work migration abroad. The situation of elderly left at home) are used to examine the influence on remittances of family commitments over time and of needs and opportunities. The sample includes 2109 parent-child dyads with data provided by elderly parents from all regions of Romania. Results of the logistic regression models show that stronger familial commitments increase the likelihood of remittances in cash and remittances in kind. Findings indicate the importance of filial support before migration and of various forms of intergenerational reciprocity. Our results stress that remittances in cash are more likely to be variable compared with remittances in kind. Both forms of support are part of a much broader set of family practices and intergenerational relationships but express different understandings of filial responsibility.
\end{abstract}

Keywords: Remittances · Intergenerational relationships · Transnational families · Family practices

\section{Introduction}

An easing of the restrictions for crossing national borders across Europe (VISA or border control elimination) along with the facilitation of work permits for foreigners in western Europe has had an enormous impact on Romanians, as well as on citizens from other eastern European countries (Horvath/Anghel 2009). Following 
the transition to market liberalism (neoliberalism) which has resulted in a struggling economy - with increasing unemployment and a high risk of poverty - a considerable number of Romanians are seeking financial security in western societies (Ban 2012; Horvath/Anghe/ 2009). Besides self-evident structural effects of international migration, at both the family and household level, migration might be a way to improve the wellbeing of the family unit and at the same time be a negative emotional experience for the kin involved. Living separated by national borders, family members need to renegotiate their active roles, responsibilities and commitments to each other (Bryceson and Vuorela 2002; Marcu 2018).

Starting from the concept of the modified extended family structure proposed by Litwak (1960), this article will address the issue of intergenerational kin connections within the transnational space, created by middle-aged Romanian migrants. The concept of generation is based here on Bengtson's definition: "ranked-descent ordering of individuals within families" (Bengtson 1993: 11). According to Litwak (1960), kin networks are a necessity for modern societies. Moreover, the author argues that kin structures have changed in response to the mobility of members in a world in which technology can lessen geographic and social distance. For instance, increased opportunities for travelling long distances (Larsen et al. 2006) and the development of easier methods of telecommunication (Madianou/Miller 2012) make contact between family members spread across the world much easier than in the past.

Among the forms of transnational care transfers often studied in research, the present paper dwells on money transfers and in-kind support to ageing parents "back home" in Romania, provided by middle-aged children living abroad. The reason for focusing on adult intergenerational relationships is that they are voluntary in nature, as intergenerational support from elderly parents or adult children is rarely regulated by national law. These relationships tend to be informal in nature and conform to unwritten laws (Wolff/Laferrère 2006). Studies of remitting practices among Romanian adult emigrants have failed so far to integrate this topic into broader research on intergenerational solidarity and care circulation. Early empirical evidence based on quantitative data addressed the variety of options for remittance transmission, determinant factors for money transfers, the amount of remittances, the use of the remittances in the homeland or the impact of these practices on the household and home country economy (World Bank Group 2016).

As a form of care that does not require face-to-face contact (Kilkey/Merla 2014; Litwak/Kulis 1987), economic support is widespread among multigenerational family units living in spatial separation. Since migration from Romania to western Europe is generally motivated by financial reasons (Ban 2012), Romanian transnational families are well-known for the importance they attach to regular remittances (Horvath/Anghel 2009; Toth 2009; Zimmer et al. 2013). According to the World Bank Group (2016), Romania was ranked third among remittance recipient countries in Europe and Central Asia. For example, more than half of Romanians living in Spain constantly send money to family members that they have left behind, mostly underage children or the spouse, and sometimes parents or grandparents (Toth 2009). Compared with other forms of intergenerational support, material assistance from 
Romanian children towards their parents is the most important type of support in transnational settings, while in the case of internal migration, intergenerational support practices are much more fluid and diverse (Zimmer et al. 2014).

Against this backdrop in current research for the case of Romania, this study seeks to analyse remittances within a theoretical framework of family-like relationships (Morgan 2011). The main contribution of the paper is to investigate remitting practices as a form of family commitment between generations, and across time and distance. Family commitments are not to be taken for granted, but are instead subject to the influence of family history, and the needs and opportunities of both elderly parents and middle-aged children. Firstly, the study aims to provide insights about how intergenerational solidarity evolves during the life course when migration is the main turning point in the life of the family. Secondly, the paper explores how various measures of family commitment, mutual support and needs and opportunities trigger remitting practices. Finally, the study seeks to identify possible differences in the meanings between remittances in cash and remittances in kind.

This study is relevant for several reasons. The first is the Romanian demographic context, involving the ageing of the population, increased international migration and population decline. Future projections of the country's population also raise concerns about the future of the family. Secondly, when trying to understand the significance of kin relations as sources of assistance, attention must be paid to the considerable importance Romanians continue to attach to family cohesion. Reports of the Population Policy Acceptance Study (European Commission 2006) show that Romanians rely heavily on help provided by the family, in both of its forms: downward (from parents to children) and upward (from children to parents) (see also Mureșan and Hărăguș 2015).

After outlining the Romanian demographic context, a theoretical framework will be briefly presented. I then explain the data and methodology used for the empirical analysis. The results section includes descriptive statistics and multivariate analysis, both for remittances in cash and remittances in kind. The later sections of the paper will discuss the findings in relation to the broader context of both literatures and the Romanian situation. The conclusions emphasize the need to investigate remittances not only from a material perspective, but also as a family practice embedded within the moral codes of kinship.

\section{The Romanian context}

At present, people in post-industrial societies have a greater life expectancy. Children will live longer than their parents, while elderly people today will live longer than in the past. In Romania, it took only 15 years (1990-2015) for the percentage of people aged $65+$ to increase from 10.4 percent to 15.5 percent (Rotariu et al. 2017). During the same period, the old-age dependency ratio has increased from 15.8 percent to 25.5 percent (Rotariu et al. 2017) and this figure is expected to continue increasing over the next period, reaching 48.2 percent in 2050 (United Nations 
2017). These trends are influenced by persistent low fertility and improving life expectancy, and also by the increased out-migration by young people.

Romania is one of the top emigration countries. Emigration flows from Romania to other member states are among the most important in the EU (World Bank Group 2016). Based on the number of immigrants by country of origin provided by each European country, the total number of Romanians in 2016 who were officially registered as residing outside Romania, but within European borders, reached almost three million people (Rotariu et al. 2017). The majority of emigrants are young adults aged between 20 and 39 (National Institute of Statistics 2015, Table 2.28), while Italy, Spain, United Kingdom and Germany are the most preferred destination countries (National Institute of Statistics 2015, Table 2.29). Unfortunately, in terms of numbers, little is known about transnational households, their multigenerational composition and the precise national situation regarding elderly people with children living abroad.

Ageing affects the structure of families and kinship networks. Research on kin availability shows that 95 percent of Romanian adults aged 20 to 39 had at least one living parent and almost 60 percent were in the age category 40 to 59 (Puur et al. 2011). The increase in the number of different generations within the same family unit (intergenerational extension) along with the reduction in the number of same generation family members (intragenerational contraction) has created beanpole families (Mureșan 2012).

Romania is one of the European countries where filial obligation is highly valued but has a low score for upward intergenerational support (Mureșan/Hărăguș 2015). Older parents expect to receive care from their children while believing that the state should be responsible for providing opportunities for young generations (Kulcsár) Brădățan 2014). A quarter of Romanian adult children live in the same household with their parents, in a context where intergenerational support is downward, from the parent towards the offspring (Hărăguș 2014). Along with strong shared norms of family obligations and widespread co-residence between parents and adult children, these cohesive support networks of kinship are necessary because of the underdeveloped Romanian social protection system, especially for the elderly (Nadolu et al. 2007).

\section{Theoretical perspectives}

Transnational families or multi-local families are defined as "families that live some or most of the time separated from each other yet hold together and create something that can be seen as a feeling of collective welfare and unity, namely 'familyhood', even across national borders" (Bryceson/Vuorela 2002: 3). This definition is captured well within the framework of "circulation of care" (Baldassar/Merla 2014). In this framework, mobility is seen as an integral part of family life with positive and negative outcomes. The framework considers both nuclear and extended family types, highlights that flows of support are multidirectional and asymmetrical, and also recognizes the importance of a life course approach (Baldassar/Merla 2014). 
Care is understood as a result of "the moral codes of family and kinship ties" and less as a commodified service, which only delivers utility (Baldassar/Merla 2014). For instance, transmission of remittances towards elderly parents is part of a longer-term social contract (Zelizer 2005).

Based on the political economy paradigm, Kolm (2008) identifies two forms of reciprocity, namely matching reciprocity and linking reciprocity. The first is associated with a moral desire to achieve a balance between the one who offers and the one who receives. Linking reciprocity, on the other hand, is a result of strong emotional bonds and a generator of further emotionally positive relationships. Reciprocity can be manifested directly when the mutual relationship is based on the same type of support or indirectly when the gift or service is different to the one received previously (Finch/Mason 1993). As a result, we expect that stronger family commitments prior to emigration and the receipt of transnational support from parents will increase the likelihood for remittances (Hypothesis H1).

Reciprocity implies that high probabilities of upward material support are linked to high probabilities of emotional assistance and frequent contact between migrant adult children and elderly parents (Baykara-Krumme/Fokkema 2018; Karpinska/ Dykstra 2018). On the other hand, strong emotional ties do not always entail material support. For example, Rooyackers and collaborators (2016) argue that affective expressions of care usually compensate for the lack of material or practical support. In addition, they found that other types of assistance are not contingent upon emotional support (Rooyackers et al. 2016). However, even though there may not be a positive causal relationship between the provision of remittances and strong emotional ties, we expect that regular contact between parents and adult children will increase the likelihood for remittances (Hypothesis $\mathrm{H} 2$ ).

Maintaining family relationships is always subject to a varying set of interdependencies. Szydlik (2016) argues that family solidarity is shaped by a group of conditional factors which he classifies into four dimensions: opportunity, need, family and cultural-contextual structures. Baldassar et al. (2007) argue that transnational exchanges of care are mediated by the capacity of individuals to engage and by the embodiment of cultural values regarding family obligations. Capacity is translated here in terms of an individual's opportunity for fulfilling familial duties across distance and is related to structural and individual factors (Baldassar et al. 2007).

One of the most important factors determining a migrant's capacity to remit is employability. Lacking job opportunities or experiencing unemployment in the country of destination reduces the migrant's income and therefore the probability of sending remittances (De Sousa/Duval 2010). Furthermore, research shows that emigrants with increased financial possibilities remit more to their family members living in the home country (Funkhouser 1995). The same author stresses that the likelihood that a migrant will send remittances will increase if his or her own children and spouse are non-migrant (Funkhouser 1995). This result is meaningful for two reasons. Firstly, it could indicate a shortage of available funds to provide intergenerational monetary help to elderly parents (lower opportunities). Secondly, the result reflects more opportunities for elderly parents to receive remittances if they 
take care of their non-migrant grandchildren, and the need of migrants to receive such support, which in turn is reciprocated by financial means.

The literature on remittances often highlights that monetary transfers from abroad to the country of origin (developing countries) are usually family-oriented and largely spent on food and basic consumption, followed by medical or health care expenses (Cox 2002; Sander 2003). Moreover, it is also reported that low-income households tend to receive more remittances (Funkhouser 1995). In this case, remittances play a major role in reducing poverty and improving quality of life for non-migrant family members. Parental needs, for financial or medical reasons, are an important trigger for remittances by migrant adult children. The third hypothesis assumes that remittances are more likely when opportunities are available for migrant children and when the needs of their elderly parents living in the country of origin are greater (Hypothesis $\mathrm{H} 3$ ).

Transfers of remittances are compound transactions, including material, emotional and relational elements (Carling 2014). Subjectivity specific to both sender and receiver is involved when remittances are transferred from the migrant to the non-migrant family members. This creates a structure that facilitates social interactions and remittances (Carling 2014). Compensation payments, repayments, allowances and other forms of help are essential for understanding the social meaning of remittance transactions (Carling 2014). Distinctions between individual motives (such as altruism, exchange, inheritance or strategic motives) and familial arrangements (insurance and investment), provide important insights into the complex set of possible motivations to remit (Rapoport/Docquier 2006). Ethnographic studies also highlight the variation of meanings of financial upward support. On the one hand, remittances for parents living in difficult financial conditions are the only available solution in order to be economically secure. On the other hand, financial transfers from adult children may be a "symbolic expression of filial piety" or simply "a matter of choice or practicality" (Baldassar et al. 2007: 86).

In a previous study in Poland, children living abroad were responsible for helping their parents financially. Remittances were valued as a symbol of children's concern and care from a distance (Krzyżowski/Mucha 2014). In the Romanian context, family solidarity and limited state support for elderly persons in poverty are the reasons for a strong flow of remittances from adult children abroad. Therefore, remittances in cash produce a safety net for the non-migrant family members. Romania is also a free market economy, with a large range of imported products and high rates of consumption (National Institute of Statistics 2019). Previous findings on smaller Romanian communities abroad show that the money which the migrants send back home is mostly spent on covering household needs (Toth 2009). We assume that remittances in cash are mostly a way to secure parents' wellbeing and financial security, while remittances in kind may, for their part, be deeper expressions of caring and are not intended to make ends meet for parents (Hypothesis $\mathrm{H} 4$ ). 
To test the research hypotheses, we used recent data from the project entitled Intergenerational solidarity in the context of work migration abroad: The situation of elderly left at home. This research project included a national survey carried out among Romanians aged 60 and over. In international demographic studies, 60 is the threshold age for the older population (UN 2015). Eligible sample members had to have at least one adult child currently working abroad. Data collection took place between April and December 2016. The analytic approach adopted in this paper focuses on the elderly parent-emigrant adult child dyad.

Data were collected from 1,506 different households and the respondent was the elderly parent (if alive, either the mother, or the father). The sampling procedure consisted of a random selection of two administrative units within each development region of Romania, followed by another random selection of towns and villages within each stratum. Respondents were identified by field survey staff through collaboration with local people: public and private institutions that maintain contacts with potential respondents (for example: city halls, social service departments, day-care centres for elderly people, organizations that provide care services). Another method for finding eligible respondents was through recommendations from already-interviewed individuals.

Most of the parents interviewed have one adult child living abroad and around 30 percent of respondents have two or more adult children living abroad. In total, our data set consists of 2,188 emigrant adult children aged 20 years or over. For 79 emigrant children (4 percent), the parents did not provide any information about either their transnational connection or previous family ties. Once these cases were excluded, the final sample includes 2,109 parent-child dyads. The variables used for this study are measurements of various types of support offered and received by elderly parents and emigrant children. In order to capture exchanges before migration, we used retrospective questions. Other questions addressed topics related to family composition, living arrangements of the nuclear family and demographics. These variables have a non-response rate of between 1 and 5 percent.

Results are presented in two different sub-sections according to the methods used for data analysis. Descriptive results are first provided in order to give the reader a sense of the sample composition. The results of the logistic regression models are then presented. Regression estimates were obtained after adjusting standard errors for correlation among adult children of the same parent. In order to achieve better explanatory power, explanatory variables measuring the types of current and past intergenerational support were recoded as dichotomous. For the analyses of remittances in cash, the original ordinal scale $(1=$ no support, $2=$ once or twice, $3=$ more than twice, $4=$ regular, at least once a month) was retained. The Polr function in $\mathrm{R}$ was used for estimating the effects of several explanatory variables on remittances in cash. In the case of remittances in kind, the $\mathrm{g} / \mathrm{m}$ function for the binomial family distribution was used. Ordinal and binary logistic regression coefficients have similar interpretations. 
Two different categories of explanatory variable are employed. The first uses measures of downward support and upward support, both before and during migration. Frequencies of ICT (information and communications technology)-mediated conversations and visits were used to assess the extent of contact between parents and children. These variables are used in order to give a sense of the family background and family history. The second category of explanatory variable comprises information about the needs and opportunities of individuals: the nuclear family context of the adult child, his or her employment status, parents' health condition and financial dependency. These variables identify the structures of opportunities and needs of both emigrant adult children and ageing parents. Some other variables were used as control factors, including country of destination, gender combination and parents' age and marital status.

Before regression modelling, all explanatory variables were checked for multicollinearity. The generalized variance inflation factor was calculated for the $\mathrm{g} / \mathrm{m}$ models. Finally, the two regression analyses, namely for remittances in cash and remittances in kind, provide final models which integrate both types of explanatory variable. The empirical results are thus based on two logistic regression models. The first model explains the variation in cash remittances using the ordinal scale, while the other model uses the binary response variable measuring remittances in kind.

Before describing the empirical results, it is necessary to assess some limitations of the data. On the one hand, the empirical evidence relies only on the parents' perspective and on their information about the personal characteristics of their children. This raises the issue of parental bias, but no information directly from the adult children is available in order to control for possible errors. Additionally, even though there is some knowledge about previous intergenerational exchanges, using cross-sectional survey data imposes limits when trying to understand how intergenerational solidarity is changing across the life course. The retrospective data used here is based on parents' memory of the past and their subjective sense of early relationships with their adult children. However, we do not believe that such limitations diminish the theoretical and empirical value of our findings.

\section{$5 \quad$ Results}

\subsection{Description of respondent characteristics and responses}

Descriptive statistics in Table 1 distinguish between several measures of intergenerational solidarity and indicators of the opportunities and needs of elderly parents and emigrant adult children. Looking at intergenerational support during migration, our results show more financial and material support overall from migrant adult children. On the other hand, parents were more involved in providing financial and material intergenerational support before migration. These results are in line with literature showing that downward intergenerational support is more frequent in a translocal context and that the direction of support usually changes after migration 
of the adult child (Finch/Mason 1993). However, parents with adult children living abroad do not only receive support, but also play active roles in transnational exchanges. Support in kind and practical help around the house are family practices that are highly present among elderly parents with emigrant adult children.

\subsection{Explaining transnational financial support. Multivariate analysis}

Considering intergenerational support in cash, the results displayed in Table 2 highlight continued upward support across time and geographic distance. Significant estimates for variables measuring intergenerational support range from 0.309 to 1.034 , where support in cash from an adult child before migration (1.034) and support in kind from an adult child during migration (0.822) are highly significant. Our results show that adult children who used to provide support in cash before emigrating are almost three times more likely to send more remittances (odds ratio $=2.812$ ), and 50 percent more likely if they had provided support in kind (odds ratio $=1.489$ ). Strong association is observed for upward support in kind during $\mathrm{mi}$ gration (0.822). The odds ratio is 2.275 , which means that the odds of sending more frequent remittances in cash are twice as high when migrants send remittances in kind as well.

Smaller and less significant regression coefficients are observed for practical support from a distance provided by elderly parents $(0.309)$. The estimated regression coefficient for monetary transnational support is significant and negative when financial support is transferred by elderly parents to emigrant adult children (-1.008). When emigrants receive money from their parents, they are 64 percent less likely to send remittances in cash. Clearly, support in cash in the context of migration is unidirectional. Migrants have the means to remit back home and parents have the means to return the support received in other ways. We do confirm Hypothesis $(\mathrm{H} 1)$ regarding previous commitments and reciprocity. Strong previous family commitments, both from adult children and elderly parents, and indirect reciprocity increase the likelihood of more frequent remittances.

At the level of family and household, Table 2 shows other explanatory factors to be significant. Our findings stress a significant association between transnational visits by emigrants and ICT contact. The two significant values of the regression estimates range from 0.619 for weekly ICT contact to 0.709 for visits. The unexpected result is the non-significant negative effect of daily ICT contact. Our second hypothesis $(\mathrm{H} 2)$ is therefore only partially confirmed.

Considering the emigrant's needs and opportunities, stepwise results (not displayed here) show significant positive association when the migrant child has a regular job (employed worker, self-employed or business owner) compared to a non-working child. Unexpectedly, the estimate in the full model is not significant anymore. Living separately from own nuclear family members accounts for the regularity of monetary support to ageing parents. In this case, the estimate varies from negative to positive values. Having underage children in Romania provides a positive association (0.428). In this case, emigrants are 50 percent more likely to send more remittances back home. A much stronger relationship regards non-coresident 
Tab. 1: Descriptive results by intergenerational solidarity and personal characteristics of migrants and non-migrant elderly parents

\begin{tabular}{|c|c|}
\hline Variable/Category & $\% /$ mean(sd) \\
\hline \multicolumn{2}{|c|}{ Support (remittances) in cash from adult child during migration } \\
\hline At least once per month & 10.1 \\
\hline More than twice a month & 22.2 \\
\hline Once or twice a month & 18.3 \\
\hline No support & 49.5 \\
\hline \multicolumn{2}{|c|}{ Support in cash from adult child before migration } \\
\hline Yes & 27.9 \\
\hline No & 72.1 \\
\hline \multicolumn{2}{|c|}{ Support in cash from parents during migration } \\
\hline Yes & 6.0 \\
\hline No & 94.0 \\
\hline \multicolumn{2}{|c|}{ Support in cash from parents before migration } \\
\hline Yes & 42.3 \\
\hline No & 57.7 \\
\hline \multicolumn{2}{|c|}{ Support (remittances) in kind from adult child during migration } \\
\hline Yes & 46.3 \\
\hline No & 53.7 \\
\hline \multicolumn{2}{|c|}{ Support in kind from adult child before migration } \\
\hline Yes & 58.2 \\
\hline No & 41.8 \\
\hline \multicolumn{2}{|c|}{ Support in kind from parents during migration } \\
\hline Yes & 35.7 \\
\hline No & 64.3 \\
\hline \multicolumn{2}{|c|}{ Support in kind from parents before migration } \\
\hline Yes & 75.8 \\
\hline No & 24.2 \\
\hline \multicolumn{2}{|c|}{ Practical support from parents in the household } \\
\hline Yes & 25.0 \\
\hline No & 75.0 \\
\hline \multicolumn{2}{|l|}{ ICT contact } \\
\hline Monthly or less & 23.0 \\
\hline Weekly & 47.9 \\
\hline Daily & 29.1 \\
\hline \multicolumn{2}{|c|}{ Visits from adult child (in the past year) } \\
\hline No & 27.6 \\
\hline Yes & 72.4 \\
\hline
\end{tabular}


Tab. 1: Continuation

\begin{tabular}{|c|c|}
\hline Variable/Category & $\% /$ mean(sd) \\
\hline \multicolumn{2}{|l|}{ Gender combination } \\
\hline Son-father & 18.6 \\
\hline Daughter-father & 18.8 \\
\hline Son-mother & 29.8 \\
\hline Daughter-mother & 32.9 \\
\hline \multicolumn{2}{|c|}{ Working status of the migrant adult child } \\
\hline Has a regular job & 87.7 \\
\hline Unemployed & 12.3 \\
\hline \multicolumn{2}{|c|}{ Children of the migrant adult child } \\
\hline No & 28.1 \\
\hline Yes, they live together & 54.1 \\
\hline Yes, living in Romania & 17.8 \\
\hline \multicolumn{2}{|c|}{ Partner of the migrant adult child } \\
\hline No & 20.7 \\
\hline Yes, they live together & 70.2 \\
\hline Yes, living in Romania & 9.2 \\
\hline \multicolumn{2}{|c|}{ Country of destination of the migrant adult child } \\
\hline Italy & 24.8 \\
\hline Spain & 19.2 \\
\hline Germany & 17.0 \\
\hline UK & 10.5 \\
\hline Other European & 21.2 \\
\hline Non-European & 7.3 \\
\hline \multicolumn{2}{|c|}{ Partnership status of the parent } \\
\hline Has partner & 56.4 \\
\hline No partner & 43.6 \\
\hline \multicolumn{2}{|c|}{ Parent's difficulties caused by health status } \\
\hline Experiencing illness & 63.7 \\
\hline No health problems & 36.3 \\
\hline \multicolumn{2}{|c|}{ Parent's capability to manage household expenses } \\
\hline No need for support & 72.4 \\
\hline No & 5.5 \\
\hline Only with support & 22.1 \\
\hline Parent's age & $67.8(6.7)$ \\
\hline $\mathrm{N}$ & 2,109 \\
\hline
\end{tabular}

Source: SolFam database, own calculation 
Tab. 2: Unstandardized coefficients of logistic regression for remittances in cash and remittances in kind to elderly parents living in Romania

\begin{tabular}{|c|c|c|}
\hline Variable/Category & $\begin{array}{l}\text { Remittances in cash } \\
\text { B (Std. Error) }\end{array}$ & $\begin{array}{c}\text { Remittances in kind } \\
\text { B (Std. Error) }\end{array}$ \\
\hline \multicolumn{3}{|l|}{ Family and household level } \\
\hline \multicolumn{3}{|c|}{ Support in cash from adult child before migration $(r e f=$ No) } \\
\hline \multirow{2}{*}{ Yes } & $1.034(0.121)^{* * *}$ & $0.072(0.161)$ \\
\hline & 2.812 & 1.075 \\
\hline \multicolumn{3}{|c|}{ Support in cash from parents during migration $(r e f=\mathrm{No})$} \\
\hline \multirow[t]{2}{*}{ Yes } & $-1.008(0.225)^{* * *}$ & $0.051(0.313)$ \\
\hline & 0.365 & 1.052 \\
\hline \multicolumn{3}{|c|}{ Support in cash from parents before migration $(r e f=\mathrm{No})$} \\
\hline \multirow{2}{*}{ Yes } & $0.219(0.113)$ & $-0.048(0.145)$ \\
\hline & 1.245 & 0.953 \\
\hline \multicolumn{3}{|c|}{ Support in cash from adult child during migration $(\mathrm{ref}=\mathrm{No})$} \\
\hline \multirow[t]{2}{*}{ Yes } & - & $1.036(0.147)^{* * *}$ \\
\hline & - & 2.818 \\
\hline \multicolumn{3}{|c|}{ Support in kind from adult child during migration $(r e f=$ No) } \\
\hline \multirow{2}{*}{ Yes } & $0.822(0.112)^{* * *}$ & - \\
\hline & 2.275 & \\
\hline \multicolumn{3}{|c|}{ Support in kind from adult child before migration $(\mathrm{ref}=\mathrm{No})$} \\
\hline \multirow[t]{2}{*}{ Yes } & $0.398(0.128)^{* *}$ & $0.843(154)^{* * *}$ \\
\hline & 1.489 & 2.323 \\
\hline \multicolumn{3}{|c|}{ Support in kind from parents during migration $(r e f=\mathrm{No})$} \\
\hline \multirow[t]{2}{*}{ Yes } & $-0.116(0.124)$ & $1.618(0.157)^{* * *}$ \\
\hline & 0.890 & 5.043 \\
\hline \multicolumn{3}{|c|}{ Support in kind from parents before migration $(r e f=\mathrm{No})$} \\
\hline \multirow[t]{2}{*}{ Yes } & $0.125(0.147)$ & $-0.157(0.181)$ \\
\hline & 1.133 & 0.855 \\
\hline \multicolumn{3}{|c|}{ Practical support from parents $(r e f=\mathrm{No})$} \\
\hline \multirow[t]{2}{*}{ Yes } & $0.309(0.124)^{*}$ & $0.325(0.160)^{*}$ \\
\hline & 1.362 & 1.384 \\
\hline \multicolumn{3}{|c|}{ ICT contact (ref=Monthly or less) } \\
\hline \multirow[t]{2}{*}{ Weekly } & $0.619(0.118)^{* * *}$ & $0.263(0.152)$ \\
\hline & 1.857 & 1.301 \\
\hline \multirow[t]{2}{*}{ Daily } & $-0.157(0.086)$ & $-0.081(0.115)$ \\
\hline & 0.855 & 0.922 \\
\hline \multicolumn{3}{|c|}{ Visits from adult child $(r e f=\mathrm{No})$} \\
\hline \multirow[t]{2}{*}{ Yes } & $0.709(0.132)^{* * *}$ & $0.651(0.161)^{* * *}$ \\
\hline & 2.032 & 1.917 \\
\hline \multicolumn{3}{|l|}{ Adult children } \\
\hline Working status $(r e f=$ Une & & \\
\hline Has a regular job & $0.237(0.188)$ & $0.264(0.214)$ \\
\hline & 1.267 & 1.302 \\
\hline Children $(r e f=\mathrm{No})$ & & \\
\hline Yes, they live together & $-0.189(0.129)$ & $0.223(0.188)$ \\
\hline & 0.828 & 1.250 \\
\hline Yes, living in Romania & $0.428(0.213)^{*}$ & $0.357(0.229)$ \\
\hline & 1.534 & 1.429 \\
\hline
\end{tabular}


Tab. 2: Continuation

\begin{tabular}{|c|c|c|}
\hline Variable/Category & $\begin{array}{c}\text { Remittances in cash } \\
\text { B (Std. Error) }\end{array}$ & $\begin{array}{l}\text { Remittances in kind } \\
\text { B (Std. Error) }\end{array}$ \\
\hline \multicolumn{3}{|l|}{ Partner $(\mathrm{ref}=\mathrm{No})$} \\
\hline \multirow[t]{2}{*}{ Yes, they live together } & $-0.127(0.148)$ & $0.122(0.204)$ \\
\hline & 0.881 & 1.130 \\
\hline \multirow{2}{*}{ Yes, living in Romania } & $-1.142(0.280)^{* * *}$ & $-0.076(0.315)$ \\
\hline & 0.319 & 0.927 \\
\hline \multicolumn{3}{|l|}{ Elderly parents } \\
\hline \multicolumn{3}{|c|}{ Difficulties caused by health status ( $r e f=$ None) } \\
\hline \multirow[t]{2}{*}{ Yes } & $0.156(0.120)$ & $-0.042(0.147)$ \\
\hline & 1.169 & 0.959 \\
\hline \multicolumn{3}{|c|}{ Capable of managing household expenses ( $r e f=$ No need for support) } \\
\hline \multirow[t]{2}{*}{ No } & $0.497(0.307)$ & $-0.352(0.311)$ \\
\hline & 1.644 & 0.703 \\
\hline \multirow[t]{2}{*}{ Only with support } & $0.734(0.131)^{* * *}$ & $-0.016(0.171)$ \\
\hline & 2.083 & 0.984 \\
\hline \multicolumn{3}{|l|}{ Control variables } \\
\hline \multicolumn{3}{|c|}{ Gender combination (ref=Son-father) } \\
\hline \multirow[t]{2}{*}{ Daughter-father } & $0.092(0.171)$ & $0.403(0.227)$ \\
\hline & 1.096 & 1.496 \\
\hline \multirow[t]{2}{*}{ Son-mother } & $0.228(0.162)$ & $0.247(0.213)$ \\
\hline & 1.256 & 1.280 \\
\hline \multirow[t]{2}{*}{ Daughter-mother } & $0.219(0.168)$ & $0.399(0.212)$ \\
\hline & 1.245 & 1.490 \\
\hline \multicolumn{3}{|l|}{ Country of destination (ref=Italy) } \\
\hline \multirow[t]{2}{*}{ Spain } & $0.010(0.156)$ & $-0.433(0.208)^{*}$ \\
\hline & 1.010 & 0.649 \\
\hline \multirow[t]{2}{*}{ Germany } & $-0.289(0.177)$ & $-0.434(0.211)$ \\
\hline & 0.749 & 0.648 \\
\hline \multirow[t]{2}{*}{ UK } & $-0.074(0.186)$ & $-0.560(0.248)^{*}$ \\
\hline & 0.929 & 0.571 \\
\hline \multirow[t]{2}{*}{ Other European } & $0.071(0.155)$ & $-0.799(0.204)^{* * *}$ \\
\hline & 1.074 & 0.450 \\
\hline \multirow[t]{2}{*}{ Non-European } & $-0.081(0.233)$ & $-0.628(0.290)^{*}$ \\
\hline & 0.922 & 0.534 \\
\hline \multicolumn{3}{|c|}{ Partnership status of the parent (ref $=$ No partner) } \\
\hline \multirow[t]{2}{*}{ Partnered } & $-0.297(0.123)^{*}$ & $0.046(0.153)$ \\
\hline & 0.743 & 1.047 \\
\hline \multirow[t]{2}{*}{ Age of the parent (continuous) } & $-0.020(0.009)^{*}$ & $0.015(0.011)$ \\
\hline & 0.980 & 1.015 \\
\hline \multicolumn{3}{|l|}{ Pseudo r-squared } \\
\hline McFadden & 0.304 & 0.389 \\
\hline Nagelkerke & 0.639 & 0.597 \\
\hline
\end{tabular}

Notes: ** $\mathrm{P} \leq 0.001$; * $\mathrm{P} \leq 0.01$; $\mathrm{P} \leq 0.05$

Odds Ratio are reported in italics below the coefficients

Source: SolFam database, own calculation 
living arrangements between spouses. Specifically, when the spouse or the partner lives in the home country, the estimate is negative and highly significant (-1.142). These are important results, stressing that family needs are highly valued among middle-aged immigrants.

In cases where parents have trouble managing household expenses without support, the likelihood of remittances being sent is doubled (odds ratio $=2.083$ ). This is the only significant result for measures of parental needs. Parental health status does not provide any significant change in the regression estimate. The lack in significance is mainly because the Romanian public medical and health care system is based on social contributions and is free of charge at the point of use for most of its medical services.

Our empirical results verify Hypothesis $(\mathrm{H} 3)$ regarding the way in which needs and opportunities shape the transmission of remittances in cash to elderly parents. Significant estimates varying from -1.141 to 0.428 for migrants who do not live abroad with their nuclear family members and 0.734 for parents who need financial support, give evidence to support our hypothesis. Transnational support through money transfers is a way of securing the wellbeing of parents. Nonetheless, children's own needs and their capacities to transfer money are important as well. For instance, their own nuclear family arrangements seem to be extremely relevant in terms of understanding intergenerational help consisting of money transfers.

Remittances in kind are significantly associated with other forms of support during migration. The values of estimates range from 1.036 for remittances in cash to 1.618 for downward support in kind. Furthermore, practical support from parents increases the likelihood of remittances in kind by 40 percent. Even though the association with practical support is not as strong as it is for material exchanges, the regression estimate is still large enough to support a generalized form of reciprocity (0.325). Previous help is also important. Adult children who used to help their parents before migration are expected to continue to offer support during migration. The regression estimate for upward support in kind before migration is highly significant (0.843). Based on our results, Hypothesis (H1) regarding previous family commitment and mutual support during migration is confirmed for remittances in kind as well.

Transnational support in kind to parents is not significantly associated with ICTcontact but only with visits to the home country. It appears that even though remittances do not require face-to-face contact, the likelihood for such exchanges is doubled (odds ratio $=1.384$ ) when emigrant children visit their parents in the origin country. Having no strong evidence for the importance of the regularity of ICT contact, the second hypothesis is therefore only partially confirmed for remittances in kind $(\mathrm{H} 2)$.

In terms of an individual's opportunities and needs, our empirical results do not show any significant associations. However, some countries of destination are associated with negative regression coefficients. Remittances in kind are less common as the distance between the home country and the country of destination increases. Our results do not provide enough reasons to confirm the third Hypothesis $(\mathrm{H} 3)$ regarding the impact of opportunities and the need for remittances in kind. 
Comparing results for remittances in cash and remittances in kind, both are heavily influenced by previous support and by the child's commitment to family solidarity. However, different types of reciprocity are observed. When considering the structures of needs and opportunities, differences arise between the two outcomes. Our evidence makes it clear that the frequency of money transfers from abroad is shaped significantly by the opportunities of the children and by the needs of the parents. This is not the case for remittances in kind, however. Also, money transfers appear to be absent except when face-to-face interaction occurs. We do confirm the last Hypothesis $(\mathrm{H} 4)$ with regards to the particularity of remittances in cash in contrast with remittances in kind.

\section{Discussion}

The effect of intergenerational support before migration was confirmed as positive. This result highlights the family-oriented type of migration which is characteristic to a large category of Romanians living abroad. The strong positive association between remittances to parents and needs underlines how the decision to migrate is related to keeping the family materially well-off. Previous research showed that 81 percent of the total amount of remittances was used to cover the daily needs of the non-migrants (Toth 2009) and that temporary migration is triggered for financial reasons (Ange/ 2009).

Asymmetry between those who offer and those who receive support was also observed. The highest odds ratio indicates that emigrant adult children tend to be providers of support. They are more likely to remit if they were involved in upward support before migration and when their transnational support consists of both remittances in cash and in kind. This is in line with other studies which show that transnational relations can be asymmetrical (Baldassar/Merla 2014). However, the involvement of parents who are beneficiaries of remittances should not be neglected. Matching reciprocity (Kolm 2008) is achieved by them providing practical help from a distance and by offering support in kind.

Regarding face-to face contact, visits to the home country seem to be an appropriate way of reconnecting with kin left behind and expressing filial piety by offering support in cash or kind to parents. Most probably, this is when emigrants also receive goods such as traditional food from their parents. Visits, along with mutual support in kind, can be understood as linking reciprocity (Kolm 2008) between elderly parents and migrant adult children. Transnational visits are considered to be the strongest way of remaining in contact and expressing togetherness (Ducu 2016).

The adult child's own nuclear family also shapes only the regularity of remittances in cash to ageing parents. We observed lower chances of intergenerational support when the spouse or partner lives in Romania and a higher likelihood when underage children live in Romania. The literature shows that grandparents usually care for the grandchildren when parents work abroad (Hărăguș et al. 2018; Kagitçibasi 2005; Treas/Mazumdar 2004). These results highlight the importance of family negotiations within the larger kin network. 
With respect to the characteristics of elderly parents, our empirical evidence shows no significant relationship between remittances in kind and parental needs. In contrast, parents experiencing financial difficulties are more likely to receive remittances in cash. Remittances in kind are more likely to be exchanged during visits motivated by special occasions such as Christian holidays, summer holidays and important family events. Support in kind is a practice of gift-giving, and has a sentimental rather than a material meaning. Previous research concluded that exchanging goods or objects creates a positive sense of attachment and gratitude (Kolm 2000) and an embodied feeling of co-presence by proxy (Baldassar et al. 2007).

The results presented here highlight the fact that remittances are not just simple practices that occur between transnational family members, but instead are embedded within the broader set of family-like activities and shaped by the individual biographies and family history. These findings build on previous work on Romanian transnational families but provide new insights.

\section{$7 \quad$ Concluding remarks}

As part of the moral economy (Minkler/Estes 1991), exchanges of care are "governed by the moral codes of family and kinship ties" (Baldassar/Merla 2014: 32). The aim of this paper was to approach the study of remitting practices as something more than simple actions that family members do or do not engage in within the context of migration. We chose to understand remittances as a family practice and part of the intergenerational relationships of support, rather than as a contribution to the macro-economy of the home country. Instead of emphasising the materiality of purely economic transactions, money and commodities were understood here in terms of means of doing family (Morgan 2011).

Our empirical evidence shows that intergenerational support in cash and in kind can be reciprocal, multidirectional and asymmetrical. As highlighted by the results above, transfers of care change over the life course, being modelled by early family context, family history, current relationships and life events. Individual characteristics, along with a degree of cultural, economic and political influence, are also important factors which determine the decision or the capacity to actively engage in supporting family from a distance. Even if we do not have strong empirical evidence to distinguish between individual willingness and individual capacity to provide remittances, we have managed to see the important link between strong family bonds and intergenerational support.

We have noticed that the patterns of transferring remittances in cash compared to remittances in kind to non-migrant elderly parents living in Romania display similarities but also clear differences. Both forms of transnational support have a certain material and sentimental value, but most importantly they are part of a broader family relationship. Even though a large proportion of emigrant adult children do not send remittances to their elderly parents living in Romania, we cannot directly assume the disruption of intergenerational family ties. Different typologies of fam- 
ily practices across borders imply that some forms of support are rather marginal while others are more intense (Baykara-Krumme/Fokkema 2018).

The limitations of the study also need to be considered. Firstly, we recorded only the parental perspective regarding the relationship with each emigrant adult child. Studies on intergenerational ambivalence regarding family support show that adult children do not always have the same opinions or perspectives as their parents (Connidis/McMullin 2002). Secondly, this paper focuses on the parent-child dyad with minimal concerns for the broader kin network. Looking at the broader kin group provides a clearer view of how responsibilities towards the family are negotiated among family members (Finch/Mason 1993). Thirdly, compared to retrospective questions (the case here), longitudinal data provides more accurate and detailed information about past events and life changes. Retrospective questions are subject to various sources of bias such as memory loss, blurred memories or misjudgements (de Vaus 2001).

Our findings and the limitations of this study suggest the need for further quantitative studies concerning Romanian families and transnational family relationships across multiple borders. Exploring normative and consensual intergenerational solidarity (Bengtson 1993; Bengtson/Roberts 1991) and acculturation in the host societies could show how social values can determine transnational care and remittances in the Romanian context. Strong family norms indicate the presence of intergenerational support (Bengtson 1993), but ambivalence can also produce changes in the subjective meaning of each family practice and differences in views between migrants and non-migrants.

In some cases, acculturation is believed to nurture family support (Rooyackers et al. 2016). However, increased differences in family systems and welfare regimes between the country of origin and the country of destination, along with a cosmopolitan type of migration (Nede/cu 2012), could lead to different forms of transnational relations among kin groups. New variations may prevail while focusing on the economic background and social capital of the migrant.

\section{Acknowledgements}

This work has been supported by a grant of the Romanian National Authority for Scientific Research and Innovation, CNCS - UEFISCDI, project number PN-II-RUTE-2014-4-1377.

\section{References}

Anghel, Remus G. 2009: Schimbare socială sau dezvoltare? Studiu de caz într-un oraș din România [Social Change or Development? Case Study for a Romanian City]. In Anghel, Remus G.; Horvath, Istvan (Eds.): Sociologia Migrației. Teorii și studii de caz românești [Sociology of Migration. Theories and Case Studies in Romania]. Iași: Polirom: 249-267. 
Baldassar, Loretta; Baldock, Cora-Vellekoop; Wilding, Raelene (Eds.) 2007: Families Caring across Borders: Migration, Ageing, and Transnational Caregiving. London: Palgrave MacMillan.

Baldassar, Loretta; Merla, Laura 2014: Locating Transnational Care Circulation in Migration and Family Studies. In: Baldassar, Loretta; Merla, Laura (Eds.): Transnational Families, Migration and the Circulation of Care: Understanding Mobility and Absence in Family Life. New York: Routledge: 25-59.

Ban, Corne/ 2012: Economic Transnationalism and its Ambiguities: The Case of Romanian Migration to Italy. In: International Migration 50,6: 129-149 [doi: 10.1111/j.14682435.2009.00556.x].

Baykara-Krumme, Helen; Fokkema, Tineke 2018: The Impact of Migration on Intergenerational Solidarity Types. In: Journal of Ethnic and Migration Studies 45,10: 1707-1727 [doi: 10.1080/1369183X.2018.1485203].

Bengtson, Vern L. 1993: Is the 'Contract across Generations' Changing? Effects of Population Ageing on Obligations and Expectations across Age Groups. In: Bengtson, Vern L.; Achenbaum, W. Andrew (Eds.): The changing Contract across Generations. New York: Aldine de Gruyter: 3-34.

Bengtson, Vern L.; Roberts, Robert E. L. 1991: Intergenerational Solidarity in Aging Families: An Example of Formal Theory Construction. In: Journal of Marriage and Family 53,4: 856-870 [doi: 10.2307/352993].

Bryceson, Deborah; Vuorela, Ulla (Eds.) 2002: The Transnational Family: New European Networks and Global Frontiers. Series on Cross-Cultural Perspectives on Women. Oxford: Berg Publishers.

Carling, Jørgen 2014: Scripting Remittances: Making Sense of Money Transfers in Transnational Relationships. In: International Migration Review 48,S1: S218-S262 [doi: 10.1111/imre.12143].

Connidis, Ingrid A; McMullin, Julie A. 2002: Sociological Ambivalence and Family Ties: A Critical Perspective. In: Journal of Marriage and Family 64,3: 558-567 [doi: 10.1111/j.1741-3737.2002.00558.x].

Cox, Donald 2002: Private Interhousehold Transfers in Vietnam in The Early and Late 1990s. Policy Research Working Paper, Report Number WPS2853. Washington DC: World Bank.

Ducu, Viorela 2016: Experiences from "Home" - Belonging to a Transnational Family. In: Romanian Journal of Population Studies X, 1: 91-104.

European Commission 2006: Population Policy Acceptance Study - The Viewpoint of Citizens and Policy Actors Regarding the Management of Population Related Change. Dialog. Final Report. Brussels: European Commission.

Finch, Janet; Mason, Jennifer (Eds.) 1993: Negotiating Family Responsibilities. London: Routledge.

Funkhouser, Edward 1995: Remittances from International Migration: A Comparison of El Salvador and Nicaragua. In: The Review of Economics and Statistics 77,1: 137-146.

Gerstel, Naomi; Gallagher, Sally K. 2001: Men's caregiving: gender and the contingent character of care. In: Gender \& Society 15,2: 197-217 [doi: 10.1177/089124301015002003].

Hărăguș, Mihaela 2014: Intergenerational Solidarity in Co-residential Living Arrangements. In: Revista de Asistență Socială XIII,4: 1-15. 
Hărăguș, Mihaela; Földes, lonuț; Savu, Veronica 2018: Older Parents in Romania as a Resource for their Migrant Adult Children. In: Ducu, Viorela; Nedelcu, Mihaela; Telegdi-Csetri, Aron (Eds.): Childhood and Parenting in Transnational Settings. Series on International Perspectives on Migration. Springer International Publishing: 155-173 [doi: 10.1007/978-3-319-90942-4_10].

Horvath, Istvan; Anghel, Remus G. 2009: Migration and its Consequences for Romania. In: Südosteuropa Journal of Politics and Society 57,4: 386-403.

Kagitcibasi, Cigdem 2005: Autonomy and Relatedness in Cultural Context: Implications for Self and Family. In: Journal of Cross-Cultural Psychology 36,4: 403-422 [doi: 10.1177/0022022105275959].

Karpinska, Kasia; Dykstra, Pearl A. 2018: Intergenerational Ties Across Borders: A Typology of the Relationships Between Polish Migrants in the Netherlands and Their Ageing Parents. In: Journal of Ethnic and Migration Studies 45,10: 1728-1745 [doi: 10.1080/1369183X.2018.1485204].

Kilkey, Majella; Merla, Laura 2014: Situating Transnational Families' Care-Giving Arrangements: The Role of Institutional Context. In: Global Networks 14,2: 210-229. [doi: 10.1111/glob.12034].

King, Russell; Castaldo, Adriana; Vullnetari, Julie 2011: Gendered Relations and Filial Duties along the Greek-Albanian Remittance Corridor. In: Economic Geography 87,4: 393-419 [doi: 10.1111/j.1944-8287.2011.01128.x].

Kolm, Serge-Chirstophe (Ed.) 2008: Reciprocity: An economics of social relations. Edinburgh/New York: Cambridge University Press.

Kolm, Serge-Chirstophe 2000: The Theory of Reciprocity. In: Gérard-Varet, Louis-Andre; Kolm, Serge-Chirstophe; Ythier, Mercier Jean (Eds.): The Economics of Reciprocity, Giving and Altruism. London: Palgrave Macmillan: 115-141.

Krzyżowski, Łukasz; Mucha, Janusz 2014: Transnational Caregiving in Turbulent Times: Polish Migrants in Iceland and Their Elderly Parents in Poland. In: International Sociology 29,1: 22-37 [doi: 10.1177/0268580913515287].

Kulcsár, László J.; Brădățan, Cristina 2014: The Greying Periphery - Ageing and Community Development in Rural Romania and Bulgaria. In: Europe-Asia Studies 66,5: 794-810 [doi: 10.1080/09668136.2014.886861].

Larsen, Jonas; Urry, John; Axhausen, Kay 2006: Mobilities, Networks, Geographies. Series on Transport and Society. Hampshire and Burlington: Ashgate Publishing.

Litwak, Eugene 1960: Geographic-Mobility and Extended Family Cohesion. In: American Sociological Review 25,3: 385-394 [doi: 10.2307/2092085].

Litwak, Eugene; Kulis, Stephen 1987: Technology, Proximity, and Measures of Kin Support. In: Journal of Marriage and the Family 49,3: 649-661 [doi: 10.2307/352210].

Madianou, Mirca; Miller, Daniel 2012: Polymedia: Towards a New Theory of Digital Media in Interpersonal Communication. In: International Journal of Cultural Studies 16,2: 169-187 [doi: 10.1177/1367877912452486].

Marcu, Silvia 2018: Mobility as a Support Strategy: Linked Lives Through the Life Course Among Eastern Europeans in Spain. In Geoforum 97: 335-342 [doi: 10.1016/j.geoforum.2018.09.034].

Minkler, Meredith; Estes, Carrol/ L. (Eds.) 1991: Critical Perspectives on Aging: The Political and Moral Economy of Growing Old. New York: Baywood Publishing Company.

Morgan, David H. J. (Ed.) 2011: Rethinking Family Practices. Series on Palgrave Macmillan Studies in Family and Intimate Life. New York: Palgrave Macmillan [doi: 10.1057/9780230304680]. 
Mureșan, Cornelia (Ed.) 2012: Schimbările comportamentului familial din România: o abordare din perspectiva cursului vieții [Changes in The Family Behaviour in Romania: The Life-course Approach]. Cluj-Napoca: Presa Universitară Clujeană.

Mureșan, Cornelia; Hărăguș, Paul-Teodor 2015: Norms of Filial Obligation and Actual Support to Parents in Central and Eastern Europe. In: Romanian Journal of Population Studies IX,2:49-81.

Nadolu, Bogdan; Nadolu, loana D.; Asay, Sylvia M. 2007: Family Strengths in Romania. In: Marriage \& Family Review 41,3-4: 419-446 [doi: 10.1300/J002v41n03 09].

National Institute of Statistics 2015: Romanian Statistical Yearbook. Romania.

National Institute of Statistics 2019: Press release [http://www.insse.ro/cms/sites/default/files/com_presa/com_pdf/ce11r18.pdf, 10.01.2018].

Nedelcu Mihaela 2012: Migrant's New Transnational Habitus: Rethinking Migration Through a Cosmopolitan Lens in the Digital Age. In: Journal of Ethic and Migration Studies 38,9: 1339-1356 [doi: 10.1080/1369183X.2012.698203].

Puur, Allan et al. 2011: Intergenerational Family Constellations in Contemporary Europe: Evidence from the Generations and Gender Survey. In: Demographic Research 25,4: 135-172 [doi: 10.4054/DemRes.2011.25.4]

Rapoport, Hellel; Docquier, Frédéric 2006: The Economics of Migrants' Remittances. In: Kolm, Serge-Christophe; Ythier, Jean Mercier (Eds.): Handbook of the Economics of Giving, Altruism and Reciprocity, Volume 2. Amsterdam: North-Holland: 1135-1198.

Rooyackers, I/se N.; De Valk, Helga A. G.; Merz, Eva-Maria 2016: Mother-child relations in adulthood within and across national borders: non-Western immigrants in the Netherlands. In: Ageing \& Society 36,10: 2010-2035.

Rotariu, Traian; Dumănescu, Luminita; Hărăgus, Mihaela (Eds.) 2017: Demografia României în Perioada Postbelică (1948-2015) [Romanian Demography between the Great World Wars (1948-2015)]. Iași: Polirom.

Ryan, Louise 2007: Migrant Women, Social Networks and Motherhood: The Experiences of Irish Nurses in Britain. In: Sociology 41,2: 295-312 [doi: 10.1177/0038038507074975].

Sander, Cerstin (Ed.) 2003: Migrant Remittances to Developing Countries. Bannock Consulting.

Sandu, Dumitru 2018: Migrația temporară în străinătate [Temporary migration abroad] In: Ghetău, Vasile (Ed.): Demografia României [Romanian Demography]. București: Editura Academiei Române.

De Sousa, José; Duval, Laetitia 2010: Geographic Distance and Remittances in Romania: Out of Sight, Out of Mind?. In: International Economics 121,1: 81-98.

Szydlik, Marc (Ed.) 2016: Sharing Lives: Adult Children and Parents. Series on Routledge Advances in Sociology. New York: Routledge.

Toth, Georgiana 2009: Remiterile de Bani ale Migrantilor Români din Regiunea Madrid și Paternurile de Utilizare a Acestora [Remittances Sent Home by Romanian Migrants in the Madrid Region and Patterns of Their Usage]. In: Sandu, Dumitru (Ed.): Comunități românești în Spania [Romanian communities in Spain]. București: Fundația Soros România: 129-141.

Treas, Judith; Mazumdar, Shampa 2004: Kinkeeping and Caregiving: Contributions of Older People in Immigrant Families. In: Journal of comparative family studies 35,1: 105-122. 
United Nations, Department of Economic and Social Affairs, Population Division 2017: World Population Prospects. The 2017 Revision. Volume I: Comprehensive Tables. New York: United Nations.

UN 2015: World Population Ageing: 2015. New York: United Nations, Department of Economic and Social Affairs, Population Division (ST/ESA/SER.A/390) [https://www. un.org/en/development/desa/population/publications/pdf/ageing/WPA2015_Report. pdf, 06.02.2020]

de Vaus, David A. (Ed.) 2001: Research Design in Social Research. London: Sage.

Vullnetari, Julie; King, Russell (Eds.) 2011: Remittances, Gender and Development: Albania's Society and Economy in Transition. London/New York: I.B.Tauris.

Wolff, Francois-Charles; Laferrere, Anne 2006: Microeconomic Models of Family Transfers. In: Kolm, Serge; Ythier, Jean Mercier (Eds): Handbook of the Economics of Giving, Altruism and Reciprocity. Volume 2. Amsterdam: North-Holland: 889-969.

World Bank Group 2016: Migration and Remittances Factbook. 3rd Edition. Washington: The World Bank [doi: 10.1596/978-1-4648-0319-2]

Zelizer, Viviana A. (Ed.) 2005: The Purchase of Intimacy. Princeton: Princeton University Press.

Zimmer, Zachary; Rada, Codrina; Stoica, Cătălin-Augustin 2014: Migration, Location and Provision of Support to Older Parents: The Case of Romania. In: Journal of Population Ageing 7,3: 161-184 [doi: 10.1007/s12062-014-9101-z].

lonuț Földes ( $\triangle$ ). Babeş-Bolyai University. Cluj-Napoca, Romania.

E-mail: ionut.foldes@gmail.com

URL: http://socasis.ubbcluj.ro/staff/ionut-foldes/ 


\section{Comparative Population Studies}

WWW.comparativepopulationstudies.de

ISSN: 1869-8980 (Print) - 1869-8999 (Internet)

\section{Published by}

Prof. Dr. Norbert F. Schneider

Federal Institute for Population Research D-65180 Wiesbaden / Germany

\section{(cc) BY-SA}

2020

\section{Managing Editor}

Prof. Dr. Johannes Huinink

Dr. Katrin Schiefer

\section{Editorial Assistant}

Beatriz Feiler-Fuchs

Wiebke Hamann

\section{Layout}

Beatriz Feiler-Fuchs

E-mail:cpos@bib.bund.de

\section{Scientific Advisory Board}

Karsten Hank (Cologne)

Michaela Kreyenfeld (Berlin)

Marc Luy (Vienna)

Natalie Nitsche (Rostock)

Zsolt Spéder (Budapest)

Rainer Wehrhahn (Kiel)

\section{Board of Reviewers}

Bruno Arpino (Barcelona)

Kieron Barclay (Rostock)

Laura Bernardi (Lausanne)

Gabriele Doblhammer (Rostock)

Anette Eva Fasang (Berlin)

Michael Feldhaus (Oldenburg)

Tomas Frejka (Sanibel)

Alexia Fürnkranz-Prskawetz (Vienna)

Birgit Glorius (Chemnitz)

Fanny Janssen (Groningen)

Frank Kalter (Mannheim)

Stefanie Kley (Hamburg)

Bernhard Köppen (Koblenz)

Anne-Kristin Kuhnt (Duisburg)

Hill Kulu (St Andrews)

Nadja Milewski (Rostock)

Roland Rau (Rostock)

Thorsten Schneider (Leipzig)

Tomas Sobotka (Vienna)

Jeroen J. A. Spijker (Barcelona)

Heike Trappe (Rostock)

Helga de Valk (The Hague)

Sergi Vidal (Barcelona)

Michael Wagner (Cologne) 